\title{
An assessment of the Coulter counter model S
}

P. H. PinkERTON, I. SPENCE, J. C. OGilvie, W. A. RONALD, PATRiCi MARCHANT, AND P. K. RAY

From the Department of Laboratory Haematology, University of Toronto Clinic, Sunnybrook Hospita雨 and the Institute of Applied Statistics, University of Toronto, Toronto, Canada

SYNOPSIS An assessment of the Coulter model S automatic blood counter has been carrie⿳亠口冋 out. The standard deviations for the haemoglobin concentration, haematocrit, red cell counfए and white cell count are, respectively, $\pm 0.15 \mathrm{~g} / 100 \mathrm{ml}, \pm 0.45 \%, \pm 0.04 \mathrm{~m} / \mathrm{c} \mathrm{mm}$, and \pm 0.49 thous/c mm. These results are clearly more accurate than careful manual estimates, performe鱼 for comparison on the same samples. Details of the comparisons are presented. A comparisof is also made with routine daily estimations.

'Carryover' from one sample to the next was found to be about $2 \%$, and tests in the ranges likely to be found in practice showed good linearity for the haemoglobin estimation, haemato crit, red cell count, and white cell count. A brief account of instrument failures is given.

The performance of the Coulter model $\mathrm{S}$ compares well with that of other automateo equipment for which detailed evaluations are available.

It is well known that, in the last two decades, there has been an unremitting increase in the work load carried by hospital laboratories but in the wake of this increase have come developments in medical laboratory technology which have permitted automation of many routine methods. A large proportion of the work load in haematology involves three measurements: haemoglobin $(\mathrm{Hb})$ concentration, haematocrit, and white cell count, and, to a much lesser extent, red cell count; recently automated instruments which determine these parameters have become available, eg, the Technicon AutoAnalyzer SMA-4 (see, for example, Lappin, Lamont, and Nelson, 1969) and the Coulter Electronics Inc. model S. The latter also directly measures or computes the mean cell volume (MCV), mean corpuscular

Received for publication 22 October 1969.

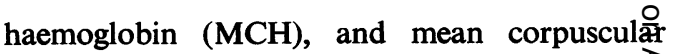
haemoglobin concentration (MCHC). We noly report our experience in assessing the Coulter model $\mathbf{S}$ for routine use in this laboratory.

\section{Apparatus and Methods}

The Coulter model $\mathbf{S}$ employs establish principles in particle counting and size analysis (Brecher, Schneiderman, and Williams, 195\%; Dacie and Lewis, 1963). The instrument consiste, in effect, of six Coulter counters, three countiog and sizing red cells and three counting white cells, together with a photosensitive device for measuing $\mathrm{Hb}$ concentration. The blood and its dilutiong, and the diluting fluids, are moved through system by a pneumatic power supply. The inf 8 - 
mation from the various measuring devices is gathered and computed electronically and presented digitally.

The instrument measures the $\mathrm{Hb}$ concentration, red cell count, MCV and white cell count directly, and computes the haematocrit from the MCV and the red cell count. The $\mathrm{MCH}$ and $\mathrm{MCHC}$ are also calculated. The time from aspiration of the sample into the instrument until presentation of results is $\mathbf{4 0}$ seconds, and the machine can accept a sample every 20 seconds, counting one while the dilutions of the next are in preparation.

A flow diagram for the Coulter model $\mathbf{S}$ is shown in Figure 1. The instrument, which is manually fed and simple to operate once standardized, aspirates about $1.3 \mathrm{ml}$ of anticoagulated blood, most of which is used to flush away the previous sample. Only $44.7 \mu \mathrm{l}$ is actually used for the estimations. This volume is diluted $1: 224$ in isotonic particle-free fluid and

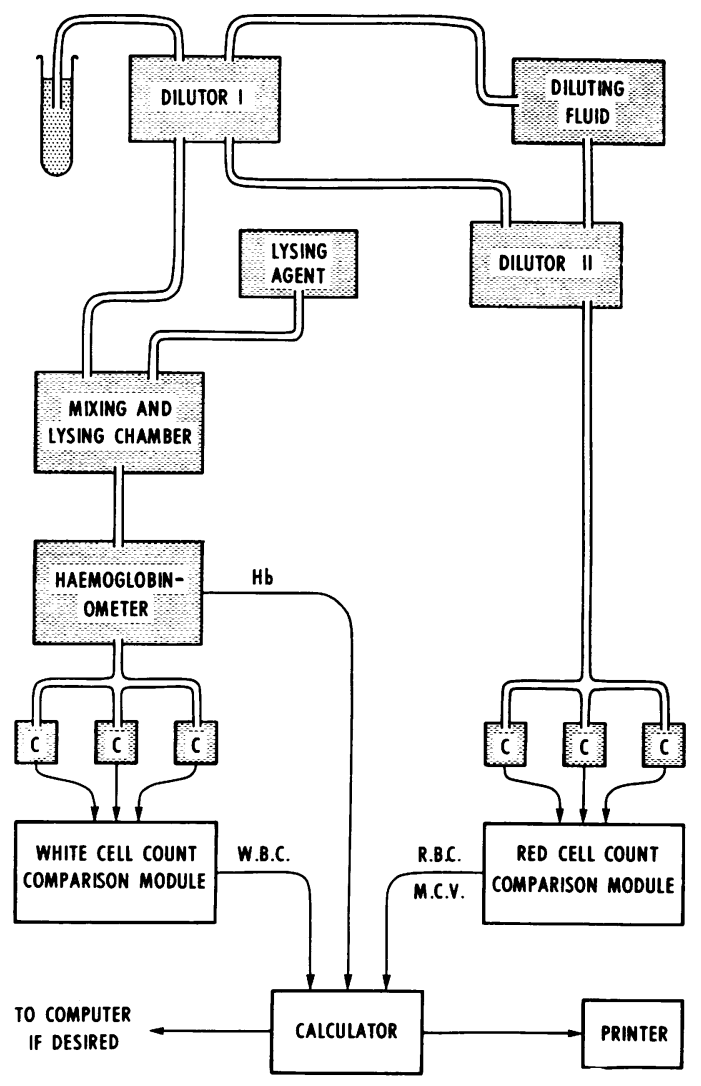

Fig. 1 Flow diagram of the Coulter model $S$. The blood sample is presented as indicated by the tube (top left). the dilution split into two aliquots. The first is $\bar{C}$ used for red cell counting and sizing after a further $\overline{\overline{\bar{J}}}$ dilution to $1: 50,000$. The second aliquot is 0 mixed with lysing agent, which converts haemo- $\vec{F}$ globin to cyanmethaemoglobin, and destroys the $\frac{\text { o }}{-}$ red cells, leaving white cells intact; the final $\overrightarrow{\vec{F}}$ dilution of this aliquot is $1: 250$. After a fixed interval for red cell lysis and haemoglobin release and conversion to cyanmethaemoglobin, $\frac{\bar{O}}{\bar{c}}$ this aliquot passes through the photosensitive $\frac{\vec{\sigma}}{\sigma}$ cells where the $\mathrm{Hb}$ concentration is measured, and $\cong$ also to the white cell counting chamber. The red $\tilde{\omega}$ cell and white cell counts are then carried out $\overrightarrow{0}$ simultaneously and in triplicate. The three results for each cell count are averaged and printed out. $\vec{\omega}$ If one result disagrees with the other two by more than 3 standard deviations of the mean? (SD) it is rejected and the other two averaged $N_{0}$ and printed out. If there is a discrepancy of more $\overrightarrow{-}$ than 3 SD between all three results, all three are $\infty$ rejected. The mean cell volume is measured ? similarly in duplicate and the mean figure printed out. The size distribution of both red and white $T$ cells can be observed on twin oscilloscope screens, 은 and the patency of the holes in the aperture tubes can also be checked visually during counting. ₹

A prediluted sample, $44.7 \mu \mathrm{l}$ of blood in $10 \mathrm{ml} \overrightarrow{0}$ of diluting fluid, can be presented to the $ठ$ instrument through a separate aspirator which 0 bypasses the first diluting step referred to above. This is of value in processing capillary blood samples.

The output from each of the six counters and $\frac{\circ}{\mathbb{D}}$ the haemoglobinometer is monitored electronic- 2 ally, correction for coincidence is made auto- $\bar{O}$ matically, and the results are fed out through an automatic digital printout. An interface can be fitted to permit direct transmission of results to a computer. (More detailed descriptions of the instrument are available from the manufacturer.) $\dot{0}$

The machine was calibrated according to the manufacturers' instructions, using their preserved $\delta$ blood standard $4 \mathrm{C}$, before each group of measure- 3 ments was carried out.

In the first group of experiments, 25 large samples of blood were taken. Each was counted by the model $\mathrm{S} 25$ times consecutively. Simultaneously and independently, two technicians $\%$ measured the haemoglobin concentration, the $N$ microhaematocrit, the red cell count, and the $\underset{\omega}{N}$ white cell count using standard manual methods (Dacie and Lewis, 1963). Haemoglobin con- 0 centrations were measured on a direct reading haemophotometer (Fisher Scientific Co.) $\stackrel{\mathcal{O}}{?}$ standardized with the International Reference $\square$ Standard haemiglobincyanide solution produced $\bar{\partial}$ for the ICSH by the Rijks Instuut voor de $\stackrel{\mathbb{D}}{\Omega}$ Volksgezondheid, Utrecht. The haemoglobin- $\mathbb{\Phi}$ ometer was standardized before each batch of $\frac{\square}{0}$ results was read. Each technician performed the manual technique in duplicate and recorded the mean value. In addition, white cell counts were performed, using a Coulter model B particle 
counter with high threshold set at 100 , the low threshold at 11 , the reciprocal of the aperture current at $\frac{1}{2}$, and the reciprocal of the amplification at $\frac{1}{2}$.

The results from the model $\mathrm{S}$ were analysed for reproducibility and were compared with the manual results.

In the second group of experiments, samples, on which $\mathrm{Hb}$ concentration, haematocrit, $\mathrm{MCHC}$, and white cell count had been performed manually as part of the routine day's work, were also counted by the model $\mathrm{S}$. The results were arbitrarily divided into three groups, of 135 , 122 , and 129 pairs, for comparison and analysis.

The degree of contamination of a sample by the previous sample ('carryover') was assessed. The model $\mathbf{S}$ was prepared by flushing three times with isotonic 'particle-free' solution and then the following procedure carried out:

1 Isotonic solution was 'counted' and the result for the 'red cell count' recorded; this was taken to represent the 'background' count and was subtracted from all subsequent counts.

2 A blood sample was put through the machine and the result rejected; a second count was performed on the same sample and the red cell count recorded.

3 Isotonic solution was then counted again and the result recorded.

4 'Carryover' was calculated by expressing the count obtained in step 3 as a percentage of that obtained in step 2 .

5 Steps 2 to 4 were repeated once.

In all, this procedure, ie, steps $1-5$, was carried out 10 times, using a total of 10 blood samples with red cell counts between 3.4 and 8.2 million c mm, giving 20 estimates of carryover.

Linearity of haemoglobin concentration, red and white cell counts, and haematocrit, as measured by the model $\mathrm{S}$ were assessed by adjusting the red cell/plasma ratio of samples of blood with added compatible plasma or by removing plasma, employing careful volumetric methods. The result obtained on the unaltered blood sample is taken as the $100 \%$ 'reference point'; the 'expected' values were then calculated and compared with the observed values obtained by counting for each of the adjusted samples.

\section{Statistical Analysis}

In analysing the first set of experiments, unless otherwise noted, we are referring to the machine performance statistics. Sample means and variances for each of the seven parameters measured were computed in the usual fashion (Mood and Graybill, 1963) and 95\% confidence intervals were calculated for each parameter over all samples. In order to obtain a more compact set of measures descriptive of the precision of the model S, seven parameter means were calculated by combining all samples, and the associated pooled within-sample variance estimates were obtained. These statistics form the basis for th calculation of the overall confidence intervals based on all 25 samples, but ignoring between: sample variation (see Table V).

In addition to visual inspection, two simple statistical tests were employed to detect the presence of outliers ('wild' observations): ( by checking that no more than one or tw observations were outside the computed $95 \%$ confidence intervals for each sample, and, (i) by computing the Studentized range statistic (Scheffé, 1959). This also proved useful för detecting and eliminating transcriptional errocs in handling data.

In order to test for 'drift' over time, the ratio (mean square successive difference)/(sample vardo ance) was computed over all 25 consecutive observations for all parameters in each samp巻 The distribution of this statistic has been derived by Hart (1942); this measure is extremely sensitive to departures from randomness. Tा

It is somewhat difficult to test the significance of the difference between the machine means and the technician means. This is partly because of the small number of technician estimates resulti $\overrightarrow{\mathrm{g}}$ in relatively few degrees of freedom for to technician variances, and partly because the machine variances are very low in comparison wigh the technician variances (see variance ratios Table VI). Since a test based on either varian $\overline{\mathrm{Q} e}$ would be unsatisfactory, and since there afe strong statistical arguments against pooling results in this kind of situation, a conventional $t$ test was not used to determine whether the machine estimates were biased. A non-paramet⿳亠口冋c binomial sign test (Bradley, 1968) was used instead, to determine whether the direction $\bar{\delta} f$ the differences, over all samples, showed aby consistent tendency.

In the second set of experiments, the degree $\&$ f agreement between man and machine was assessed by computing product-moment correlation coefficients (Mood and Graybill, 1963) between the model $\mathbf{S}$ estimates and a technicia뽀‥ results.

\section{Results}

THE PRECISION OF RESULTS

The agreement between a series of estimations $\stackrel{\Phi}{Q n}_{n}$ each of 25 samples has been determined for eagh of the seven parameters measured by the Coulerer model $\mathrm{S}$. The results of these estimations reffigct the consistency of the instrument, and Pe presented in Tables I-IV. The mean value for the Coulter model $\mathrm{S}$ and the $95 \%$ confidence limits are shown with the mean manual value 80 comparison. The presence of statistically nificant 'drift' is indicated. In most instanæi 
Table I Precision of haemoglobin and haematocritesti mations expressed as means and $95 \%$ confidence intervals by machine compared with mean manual estimates

'Significant dis ift down.

'One set of results in this sample was out of keeping with the other $24(\mathrm{Hb}=4.6 \mathrm{~g} / 100 \mathrm{ml})$; no explanation is now apparent, but this anomalous type of result was not subsequently observed in any other group of experiments.

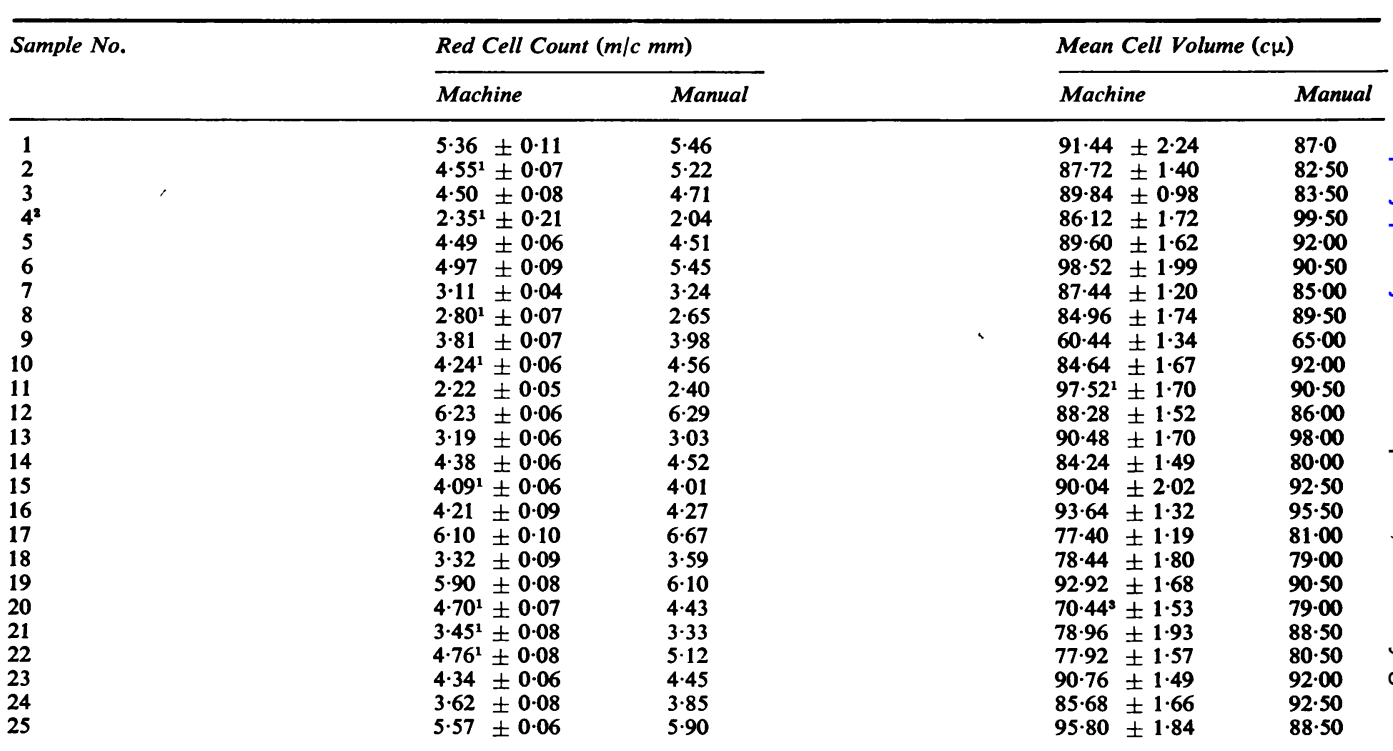

Table II Precision of red cell count and mean cell volume estimations expressed as means and $95 \%$ confidence intervals by machine compared with mean manual estimates

1,2 see Table I.

3 Significant drift up. 


\begin{tabular}{|c|c|c|c|c|}
\hline \multirow[t]{2}{*}{ Sample No. } & \multicolumn{2}{|l|}{$M C H(p g)$} & \multicolumn{2}{|l|}{$M C H C(\%)$} \\
\hline & Machine & Manual & Machine & Manuक \\
\hline 1 & $30.78^{1} \pm 1.48$ & $30 \cdot 50$ & $33.50^{1} \pm 1.67$ & 34.00 으 \\
\hline 2 & $30.22 \pm 0.79$ & $27 \cdot 80$ & $33.90 \pm 0.70$ & $34.80 \div$ \\
\hline 3 & $31.23 \pm 0.44$ & $29 \cdot 25$ & $34.55 \pm 0.76$ & 35.00 定 \\
\hline 4 & $28.00 \pm 0.75$ & $34 \cdot 50$ & $32.13 \pm 0.85$ & $31 \cdot 20 \stackrel{\mathrm{C}}{\longrightarrow}$ \\
\hline 5 & $30.67 \pm 0.55$ & $30 \cdot 45$ & $33.83 \pm 0.78$ & $34.00 \mathrm{O}$ \\
\hline 6 & $33.02 \pm 0.54$ & $30 \cdot 20$ & $33.32 \pm 0.48$ & $33.95 \frac{\mathrm{C}}{\Omega}$ \\
\hline 7 & $28.01 \pm 0.50$ & $27 \cdot 75$ & $32 \cdot 10 \pm 0.76$ & $31 \cdot 10 \stackrel{\sigma}{=}$ \\
\hline 8 & $29.21^{1} \pm 0.87$ & $29 \cdot 15$ & $34.50^{1} \pm 0.98$ & $33.00 \frac{\bar{\sigma}}{\partial}$ \\
\hline 9 & $19 \cdot 12 \pm 0.32$ & $18 \cdot 15$ & $30.74 \pm 0.99$ & $27 \cdot 45 \stackrel{D}{D}$ \\
\hline 10 & $29.13^{1} \pm 0.61$ & $27 \cdot 10$ & $34.08^{1} \pm 0.82$ & 29.50 르 \\
\hline 11 & $33.70 \pm 0.70$ & $29 \cdot 60$ & $33.40 \pm 1.00$ & 31.60 \\
\hline 12 & $34.10 \pm 0.48$ & $31 \cdot 05$ & $30.04 \pm 0.33$ & 32.950 \\
\hline 13 & $31.87 \pm 0.65$ & $31 \cdot 40$ & $35.16 \pm 0.68$ & $33.90 \bar{C}$ \\
\hline 14 & $28.93^{1} \pm 0.77$ & $27 \cdot 80$ & $34.24 \pm 1.04$ & $34 \cdot 20$. \\
\hline 15 & $31.90 \pm 0.54$ & $31 \cdot 80$ & $35.27 \pm 0.54$ & $34.45=$ \\
\hline 16 & $32.41 \pm 0.56$ & $32 \cdot 05$ & $34.44 \pm 0.62$ & $34.30 \mathrm{c}$ \\
\hline 17 & $25.95 \pm 0.47$ & $24 \cdot 05$ & $33.30 \pm 0.58$ & $29.75 \bigcirc$ \\
\hline 18 & $26.75 \pm 0.77$ & 23.95 & $33.84 \pm 0.90$ & 29.85 은 \\
\hline 19 & $31.96 \pm 0.44$ & $30 \cdot 50$ & $34.00 \pm 0.45$ & $34.70 ?$ \\
\hline 20 & $22.91 \pm 0.34$ & $22 \cdot 45$ & $32 \cdot 10 \pm 0.57$ & $28.65 \hat{\mathrm{C}}$ \\
\hline 21 & $27 \cdot 11^{3} \pm 0.57$ & $27 \cdot 40$ & $34.40 \pm 0.79$ & $29 \cdot 15=$ \\
\hline 22 & $26 \cdot 10^{3} \pm 1 \cdot 78$ & $24 \cdot 20$ & $33 \cdot 71^{3} \pm 2 \cdot 20$ & 30.05 " \\
\hline 23 & $32.16 \pm 0.49$ & $32 \cdot 05$ & $35 \cdot 12 \pm 0.60$ & 34.85 ఠ \\
\hline 24 & $29.05 \pm 0.58$ & $27 \cdot 10$ & $33.69 \pm 1.35$ & 29.500 \\
\hline 25 & $33.71 \pm 0.40$ & $32 \cdot 15$ & $34.70 \pm 0.42$ & $35 \cdot 40$ 号 \\
\hline
\end{tabular}

Table III Precision of mean corpuscular haemoglobin and mean corpuscular haemoglobin concentratigh estimations expressed as means and $95 \%$ confidence intervals by machine compared with mean manual estimates $1,{ }^{2}$ see Table I

${ }^{3}$ see Table II.

\begin{tabular}{|c|c|c|c|}
\hline \multirow[t]{2}{*}{ Sample No. } & \multicolumn{3}{|c|}{ White Cell Count $(1,000 / \mathrm{c} \mathrm{mm})$} \\
\hline & Model $S$ & Manual & Model B \\
\hline 1 & $6 \cdot 79^{1} \pm 1 \cdot 70$ & 5.95 & $5 \cdot 30$ \\
\hline 2 & $6.36^{3} \pm 0.46$ & $6 \cdot 50$ & $6 \cdot 50$ \\
\hline 3 & $6 \cdot 96^{3} \pm 1 \cdot 10$ & $6 \cdot 80$ & $6 \cdot 50$ \\
\hline $4^{2}$ & $10.27 \pm 2.22$ & $10 \cdot 40$ & $12 \cdot 25$ \\
\hline 5 & $4.46 \pm 0.22$ & $4 \cdot 70$ & $5 \cdot 35$ \\
\hline 6 & $9.04 \pm 0.28$ & $10 \cdot 45$ & $9 \cdot 50$ \\
\hline 7 & $6.59 \pm 2.42$ & $7 \cdot 60$ & $6 \cdot 25$ \\
\hline 8 & $5 \cdot 40^{3} \pm 1 \cdot 12$ & $6 \cdot 30$ & $5 \cdot 25$ \\
\hline 9 & $7 \cdot 18 \pm 0.24$ & $7 \cdot 70$ & $7 \cdot 70$ \\
\hline 10 & $4.95 \pm 0.26$ & $6 \cdot 35$ & $5 \cdot 80$ \\
\hline 11 & $3.99 \pm 0.23$ & 3.90 & 4.05 \\
\hline 12 & $9.20 \pm 0.21$ & $8 \cdot 45$ & $9 \cdot 00$ \\
\hline 13 & $8.54^{1} \pm 0.34$ & $7 \cdot 75$ & $8 \cdot 10$ \\
\hline 14 & $7.58 \pm 0.26$ & $7 \cdot 85$ & 7.95 \\
\hline 15 & $5.51 \pm 0.25$ & 5.85 & $5 \cdot 80$ \\
\hline 16 & $6.93 \pm 0.29$ & $7 \cdot 75$ & $7 \cdot 75$ \\
\hline 17 & $7.38 \pm 0.46$ & 6.85 & $7 \cdot 50$ \\
\hline 18 & $30.66 \pm 2.06$ & $37 \cdot 65$ & $31 \cdot 70$ \\
\hline 19 & $10.67 \pm 0.40$ & $12 \cdot 20$ & $11 \cdot 40$ \\
\hline 20 & $8.13 \pm 0.25$ & 8.95 & $8 \cdot 45$ \\
\hline 21 & $5 \cdot 02^{1} \pm 0.29$ & $5 \cdot 20$ & $4 \cdot 55$ \\
\hline 22 & $5.76 \pm 0.57$ & $6 \cdot 15$ & $5 \cdot 80$ \\
\hline 23 & $7.00 \pm 0.23$ & 6.05 & $6 \cdot 85$ \\
\hline 24 & $9.28 \pm 0.27$ & $9 \cdot 25$ & $8 \cdot 85$ \\
\hline 25 & $9.02 \pm 0.15$ & $8 \cdot 80$ & $9 \cdot 10$ \\
\hline
\end{tabular}

Table IV Precision of white cell count estimations expressed as means and $95 \%$ confidence intervals by machine compared with mean manua estimates using a haemocytometer and a Coulter model B

1,2 see Table I.

see Table II. without highly sensitive statistical analysis, drist would not have been detected, and was rare apparent on casual inspection of results. Table V, the overall $95 \%$ confidence interval for each parameter by manual and automa methods is presented, giving a compact assessmett of the reproducibility of results. In only ofe sample (number 4) was a 'wild' set of resulss obtained. This was readily detected by simple inspection of the results.

\begin{tabular}{|c|c|c|}
\hline \multirow[t]{2}{*}{ Blood Test Parameter } & \multicolumn{2}{|c|}{$95 \%$ Confidence Interval } \\
\hline & Coulter Model S & $\begin{array}{l}\text { Manual } \\
\text { Methods }\end{array}$ \\
\hline $\begin{array}{l}\mathrm{Hb}(\mathrm{g} / 100 \mathrm{ml}) \\
\operatorname{PCV}(\%) \\
\operatorname{RCC}(\mathrm{m} / \mathrm{c} \mathrm{mm}) \\
\operatorname{MCV}(\mathrm{c} \mu) \\
\operatorname{MCH}(\mathrm{pg}) \\
\operatorname{MCHC}(\%) \\
\text { WBC }(1,000 / \mathrm{c} \mathrm{mm})\end{array}$ & $\begin{array}{r}12 \cdot 16-12 \cdot 76 \\
36 \cdot 11-37 \cdot 87 \\
4 \cdot 16-4 \cdot 35 \\
84 \cdot 60-87 \cdot 66 \\
28 \cdot 84-30 \cdot 20 \\
32 \cdot 66-34 \cdot 54 \\
7 \cdot 18-9 \cdot 04\end{array}$ & $\begin{array}{r}12 \cdot 01-12 \cdot 85 \\
36 \cdot 70-39 \cdot 99 \\
3 \cdot 64-5 \cdot 1 \frac{19}{76 \cdot 53-97 \cdot 90} \\
24 \cdot 27-32 \cdot 65 \\
30 \cdot 39-34 \cdot 19 \\
7 \cdot 03-9 \cdot 85\end{array}$ \\
\hline
\end{tabular}

Table V Overall $95 \%$ confidence intervals computed over all samples ignoring between-sample variation $\stackrel{\mathbb{2}}{\Omega}$ 


\begin{tabular}{|c|c|c|c|c|c|c|c|}
\hline \multirow[t]{3}{*}{ Blood Test Parameter } & \multicolumn{6}{|c|}{ Pooled Within-sample Variances and Standard Deviations } & \multirow{3}{*}{$\begin{array}{l}\text { Variance } \\
\text { Ratios } \\
\text { Technician: } \\
\text { Machine }\end{array}$} \\
\hline & \multicolumn{3}{|c|}{ Machine } & \multicolumn{3}{|c|}{ Technician } & \\
\hline & Mean & Variance & $S D$ & Mean & Variance & $S D$ & \\
\hline $\begin{array}{l}\mathrm{Hb}(\mathrm{g} / 100 \mathrm{ml}) \\
\operatorname{PCV}(\%) \\
\operatorname{RCC}(\mathrm{m} / \mathrm{c} \mathrm{mm}) \\
\operatorname{MCV}(\mathrm{c} \mu) \\
\operatorname{MCH}(\mathrm{pg}) \\
\operatorname{MCHC}(\%) \\
\operatorname{WBC}(1,000 / \mathrm{c} \mathrm{mm})\end{array}$ & $\begin{array}{r}12 \cdot 46 \\
36 \cdot 99 \\
4 \cdot 25 \\
86 \cdot 13 \\
29 \cdot 52 \\
33 \cdot 69 \\
8 \cdot 11\end{array}$ & $\begin{array}{l}0.024 \\
0 \cdot 200 \\
0 \cdot 002 \\
0 \cdot 610 \\
0 \cdot 125 \\
0 \cdot 228 \\
0 \cdot 223\end{array}$ & $\begin{array}{l}0.15 \\
0.45 \\
0.04 \\
0.78 \\
0.35 \\
0.48 \\
0.47\end{array}$ & $\begin{array}{r}12 \cdot 43 \\
38 \cdot 02 \\
4 \cdot 39 \\
87 \cdot 22 \\
28 \cdot 46 \\
32 \cdot 29 \\
8 \cdot 44\end{array}$ & $\begin{array}{r}0.042 \\
0.408 \\
0.130 \\
26.833 \\
4.112 \\
0.851 \\
0.464\end{array}$ & $\begin{array}{l}0 \cdot 20 \\
0 \cdot 64 \\
0 \cdot 36 \\
5 \cdot 18 \\
2 \cdot 03 \\
0 \cdot 92 \\
0 \cdot 46\end{array}$ & $\begin{array}{r}1 \cdot 79 \\
2 \cdot 04 \\
3 \cdot 10 \\
43 \cdot 96 \\
32 \cdot 81 \\
3 \cdot 74 \\
2 \cdot 01\end{array}$ \\
\hline
\end{tabular}

Table VI Comparison of the reproducibility of machine and manual estimates of seven blood test parameters

THE ACCURACY OF RESULTS

This may be defined as the measure of closeness of observed and 'true' values. The determination of 'true' values for haematological measurements for comparison with those obtained by the

\begin{tabular}{lll}
\hline $\begin{array}{l}\text { Blood Test } \\
\text { Parameter }\end{array}$ & $\begin{array}{l}\text { No. of Positive } \\
\text { Differences in } \\
\text { 25 Samples }\end{array}$ & $\begin{array}{l}\text { Probability of } \\
\text { Occurrence }\end{array}$ \\
\hline HB & 13 & Not significant \\
PCV & 16 & Not significant \\
RCC & 19 & $<0 \cdot 05$ \\
MCV & 15 & Not significant \\
MCH & 2 & $<0 \cdot 01$ \\
MCHC & 8 & Not significant \\
WBC & 15 & Not significant \\
\hline
\end{tabular}

Table VII Binomial sign test of significance of differences between machine and technician means

\begin{tabular}{|c|c|c|c|c|c|c|}
\hline \multirow[t]{2}{*}{ Group } & \multicolumn{3}{|c|}{$\begin{array}{l}\text { Haemoglobin Concentration } \\
(\mathrm{g} / 100 \mathrm{ml})\end{array}$} & \multicolumn{3}{|c|}{ Haematocrit $(\%)$} \\
\hline & $\begin{array}{l}\text { Machine } \\
\text { Mean }\end{array}$ & $\begin{array}{l}\text { Manual } \\
\text { Mean }\end{array}$ & $\begin{array}{l}\text { Correlation } \\
\text { Coefficient }\end{array}$ & $\begin{array}{l}\text { Machine } \\
\text { Mean }\end{array}$ & $\begin{array}{l}\text { Manual } \\
\text { Mean }\end{array}$ & $\begin{array}{l}\text { Correlation } \\
\text { Coefficient }\end{array}$ \\
\hline $\begin{array}{l}\text { I } \\
(135)^{1}\end{array}$ & $13 \cdot 85$ & $14 \cdot 04$ & 0.971 & $40 \cdot 23$ & $41 \cdot 74$ & 0.853 \\
\hline $\begin{array}{l}\text { II } \\
\text { (122) }\end{array}$ & 13.93 & $14 \cdot 02$ & 0.972 & $41 \cdot 31$ & 42.09 & 0.764 \\
\hline III & 13.95 & $14 \cdot 19$ & 0.977 & $41 \cdot 21$ & $41 \cdot 70$ & 0.807 \\
\hline
\end{tabular}

Table VIIIa Comparison between routine work performed manually and by Coulter model $S$

${ }^{1}$ Numbers in each group.

\begin{tabular}{|c|c|c|c|c|c|c|}
\hline \multirow[t]{2}{*}{ Group } & \multicolumn{3}{|c|}{$\begin{array}{l}\text { Mean Corpuscular Haemoglobin } \\
\text { Concentration }(\%)\end{array}$} & \multicolumn{3}{|c|}{ White Cell Count $(1,000 / \mathrm{c} \mathrm{mm})$} \\
\hline & $\begin{array}{l}\text { Machine } \\
\text { Mean }\end{array}$ & $\begin{array}{l}\text { Manual } \\
\text { Mean }\end{array}$ & $\begin{array}{l}\text { Correlation } \\
\text { Coefficient }\end{array}$ & $\begin{array}{l}\text { Machine } \\
\text { Mean }\end{array}$ & $\begin{array}{l}\text { Manual } \\
\text { Mean }\end{array}$ & $\begin{array}{l}\text { Correlation } \\
\text { Coefficient }\end{array}$ \\
\hline $\begin{array}{l}\text { I } \\
(135)^{1}\end{array}$ & $34 \cdot 46$ & $33 \cdot 25$ & 0.437 & $7 \cdot 92$ & $8 \cdot 52$ & 0.923 \\
\hline $\begin{array}{l}\text { II } \\
\text { (122) }\end{array}$ & 33.95 & $32 \cdot 99$ & 0.478 & $8 \cdot 59$ & 8.98 & $0 \cdot 870$ \\
\hline $\begin{array}{l}\text { III } \\
\text { (129) }\end{array}$ & $33 \cdot 54$ & $33 \cdot 15$ & $0 \cdot 776$ & $8 \cdot 71$ & $9 \cdot 41$ & 0.931 \\
\hline
\end{tabular}

Table VIIIb Comparison between routine work performed manually and by Coulter model $S$

${ }^{1}$ Numbers in each group.
Coulter model $\mathbf{S}$ is difficult, as manual techniques are hard to standardize accurately and fraught $\stackrel{\omega}{\sigma}$ with potential sources of error. Furthermore, the Coulter model $\mathbf{S}$ is itself calibrated using $a_{i}$ standard of preserved blood in which the $\omega$ parameters have been determined either manually $\vec{\sigma}$ or by another instrument. Thus, an assessment ${ }^{\infty}$ of accuracy of the Coulter model $\mathrm{S}$ is rather a $\mathrm{S}$ comparison of the Coulter model $S$ with the results of manual estimations done $(a)$ especially $\mathbb{D}$ for comparison with the instrument and $(b)$ as part of the daily routine work of the Department. The results for $(a)$ are presented in Tables I-VI where the mean manual and mean machine results $\vec{\theta}$ are compared. The degree of within-sample. variation by the model $S$ and by the manual methods is shown in Table VI, which also gives the manual : machine variance ratio.

In Table VII an analysis of the differences between the mean results for the manual and $\stackrel{D}{D}$ machine estimates of the seven parameters is $\Rightarrow$ presented. By the manual technique, the red cell counts are significantly higher than those obtained by the model $\mathrm{S}$ and the $\mathrm{MCH}$ values are significantly lower. This relationship would be expected in view of the close correlation between? manual and machine haemoglobin estimations (see Tables I, VII, and VIII).

No correlation was detected between the $\mathrm{Hb}$ concentration, haematocrit, red cell count, $\mathrm{MCV}, \mathrm{MCH}$, or $\mathrm{MCHC}$ and the variance of 5 these parameters. However, when the white cell $D$ count results were examined, they were found to be significantly $(\mathrm{P}<0.05)$ less reproducible N when the white cell count was high.

In Table VIII the results of comparison of the ordinary routine work and the instrument counts $\omega$ are shown, together with their correlation coefficients. The degree of correlation for the haemoglobin concentration, white cell count, $\bar{\Phi}$ and haematocrit is high, but that for the $\mathrm{MCHC}^{\text {? }}$ is comparatively poor.

\section{CARR Y OVER}

The mean background count in the red-cello channel for isotonic solution was $0.023 \times 10^{6} 8$ per c mm with a range of 0 to $0.04 \times 10^{6}$. The mean of 20 estimates of carryover was $1.96 \%$ with a range of 1.1 to $2.7 \%$. 
P. H. Pinkerton, I. Spence, J. C. Ogilvie, W. A. Ronald, Patricia Marchant, and P. K. Ray

\begin{tabular}{|c|c|c|c|c|c|c|c|c|c|c|c|}
\hline \multicolumn{2}{|c|}{ Parameter } & \multicolumn{5}{|c|}{ Sample 1} & \multicolumn{5}{|c|}{ Sample 2} \\
\hline & & \multicolumn{5}{|c|}{ Tube Number ${ }^{1}$} & \multicolumn{5}{|c|}{ Tube Number 1} \\
\hline & & 1 & 2 & 3 & 4 & 5 & 1 & 2 & 3 & 4 & 5 \\
\hline \multirow{2}{*}{$\mathbf{H b}$} & Observed & 16.9 & $8 \cdot 7$ & 6.4 & $4 \cdot 3$ & $2 \cdot 6$ & 一 & $10 \cdot 5$ & $8 \cdot 0$ & $5 \cdot 4$ & $3 \cdot 2$ 㡍 \\
\hline & Expected & 16.9 & $8 \cdot 5$ & 6.4 & $4 \cdot 2$ & $2 \cdot 4$ & - & $10 \cdot 5$ & $7 \cdot 9$ & $5 \cdot 2$ & $3 \cdot 20$ \\
\hline \multirow[t]{2}{*}{ PCV } & Observed & $50 \cdot 1$ & $26 \cdot 6$ & $19 \cdot 1$ & $12 \cdot 5$ & $7 \cdot 7$ & - & $30 \cdot 2$ & $23 \cdot 0$ & $15 \cdot 5$ & $9 \cdot 50$ \\
\hline & Expected & $51 \cdot 1$ & $25 \cdot 5$ & $19 \cdot 2$ & $12 \cdot 8$ & $7 \cdot 7$ & - & $30 \cdot 8$ & $23 \cdot 1$ & $14 \cdot 4$ & $9 \cdot 2 巨$ \\
\hline \multirow[t]{2}{*}{ RCC } & Observed & $5 \cdot 55$ & $2 \cdot 89$ & $2 \cdot 11$ & $1 \cdot 39$ & 0.85 & - & $3 \cdot 17$ & 2.40 & $1 \cdot 62$ & $1.0 \underline{\underline{T}}$ \\
\hline & Expected & $5 \cdot 60$ & $2 \cdot 90$ & $2 \cdot 10$ & $1 \cdot 40$ & 0.85 & - & $3 \cdot 13$ & $2 \cdot 35$ & $1 \cdot 51$ & $0.9 \varphi \underline{9}$ \\
\hline \multirow[t]{2}{*}{ WCC } & Observed & $8 \cdot 1$ & $4 \cdot 3$ & $3 \cdot 1$ & $2 \cdot 2$ & $1 \cdot 3$ & - & $37 \cdot 9$ & $29 \cdot 9$ & $20 \cdot 1$ & $11 \cdot 3 \vec{\Phi}$ \\
\hline & Expected & $8 \cdot 1$ & $4 \cdot 1$ & $3 \cdot 1$ & $2 \cdot 0$ & $1 \cdot 2$ & - & $37 \cdot 8$ & $28 \cdot 3$ & $18 \cdot 9$ & 11.30 \\
\hline MCV & Observed & 91 & 93 & 92 & 92 & 92 & - & 95 & 96 & 96 & لט 95 \\
\hline $\mathrm{MCH}$ & Observed & $29 \cdot 8$ & $29 \cdot 6$ & $29 \cdot 7$ & $30 \cdot 7$ & $30 \cdot 1$ & - & 33.9 & $32 \cdot 9$ & 33.4 & $32 \cdot 0^{\infty}$ \\
\hline MCHC & Observed & $33 \cdot 6$ & $32 \cdot 8$ & $33 \cdot 4$ & $34 \cdot 6$ & $33 \cdot 6$ & - & $35 \cdot 0$ & $34 \cdot 7$ & $35 \cdot 2$ & $34 \cdot 1 \overrightarrow{0}$ \\
\hline
\end{tabular}

Table IX The results of tests of linearity on two samples of blood diluted or concentrated by the addition removal of plasma (see methods)

${ }^{1}$ Tube number 1 contains blood concentrated to $133 \frac{1}{3} \%$ of the original by removal of plasma. Tubes 2 , 3, 4, and 5 contain blo $\mathrm{d}$. diluted with plasma to $66 \frac{2}{3}, 50,33 \frac{1}{8}$, and $20 \%$ respectively of the original. The observed values for the unaltered blood sample are taken as the $100 \%$ 'reference' point.

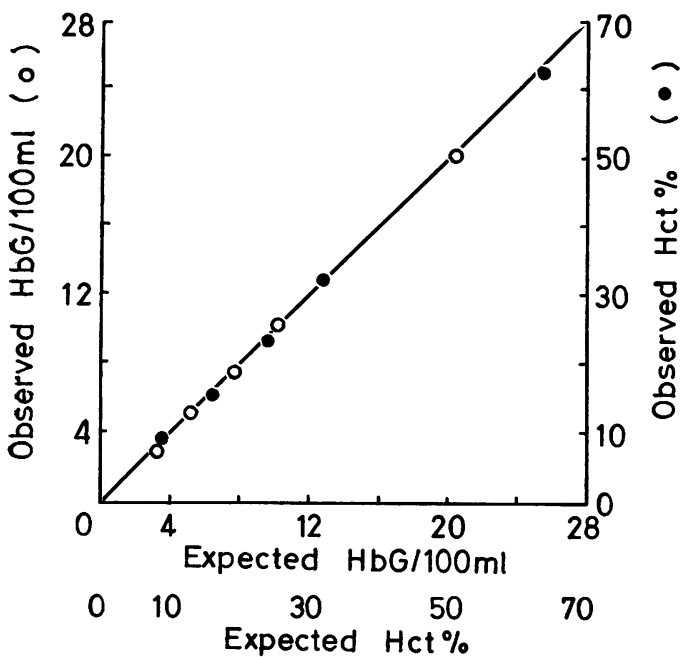

Fig. 2 Linearity for haemoglobin concentration and haematocrit. The line represents perfect correlation between 'observed' and 'expected' values, and the symbols give the results actually obtained.

\section{LINE A R ITY}

The results of estimates of linearity for two samples are presented in Table IX and Figures 2 and 3 illustrate a typical set of results for a third sample. The results are linear in the ranges tested, ie, $\mathrm{Hb} 2-24 \mathrm{~g} / 100 \mathrm{ml}$; haematocrit, 6-70\%; red cell count $0 \cdot 7-8.0 \mathrm{~m} / \mathrm{c} \mathrm{mm}$; white cell count, $1 \cdot 0-50,000 /$ cu $\mathrm{mm}$.

As can be seen from Table IX the results for
Fig. 3 Linearity for red cell count and white cell count. The line represents perfect correlation betweef 'observed' and 'expected' values, and the symbols give the results actually obtained.

$\mathrm{MCV}, \mathrm{MCH}$, and $\mathrm{MCHC}$ remain constant withim the limits of error of the machine. Resū $\bar{s}$ obtained from three further samples we similar to those presented.

\section{INSTRUMENT FAILURES}

Minor faults such as blocked aperture tubes å̊d drainage tubes are quite frequent and usuafly easily detected and remedied. Less easily detected 
and less frequent are loose electronic circuit cards, but once found this fault is also easily remedied.

More major instrument failures occur occasionally and generally require replacement of parts. While these faults are often easily diagnosed, it is usually necessary to seek assistance from the manufacturer, at least in obtaining the necessary spare parts. We have observed in six months' operation: failure of the blood sampling valve, requiring replacement; failure of the mechanical mechanism in one digital printout system; failure of several electronic circuit cards requiring replacement; looseness of the joints between aperture tubes and the flange on which they are mounted; failure of the lamp in the automatic haemoglobinometer.

In no instance has the model $\mathrm{S}$ been out of commission for more than one day, and has usually been repaired within three hours of discovery of the fault.

\section{Discussion}

The reproducibility achieved by the Coulter model $\mathbf{S}$ in this study is comparable with that found by Barnard, Carter, Crosland-Taylor, and Stewart (1969), also using a Coulter model S, and with that reported by Nelson and his colleagues in their evaluation of the Technicon AutoAnalyzer SMA-4 (Lappin et al, 1969), and the SMA-7A (Nelson, 1969a).

It is clear from the variance ratios (see Table VI) that the results using the Coulter model $\mathrm{S}$ are much more reproducible than those obtained by manual methods. The only directly measured parameter which showed a significant and consistent difference between manual and machine counts was the red cell count which tended to be higher when counted by hand. Since the haemoglobin estimations were in good agreement by both techniques, a significant difference, in the opposite direction, was seen in the $\mathrm{MCH}$ value.

When results obtained during routine daily work were compared with those obtained from the model S, there was good correlation for the haemoglobin concentration. However, the correlation for the haematocrit determination was less good and this may reflect the well known inaccuracies of microhaematocrit estimations. It may also in part reflect the fact that the haematocrit estimation performed by the model $\mathrm{S}$ is computed from two other measurements (red cell count and MCV) thus compounding the opportunity for error. The correlation coefficients for the MCHC are rather poor; this, again, may reflect technical inaccuracies in the manual methods and the use of three parameters by the model $\mathbf{S}(\mathrm{Hb}$, red cell count, MCV) to calculate the mean corpuscular haemoglobin concentration. The correlation coefficients for the white cell counts indicate good agreement.

The potential range of error in any parameter except the white cell count is not influenced by the value obtained for that parameter in the ranges tested here. However, when the white cello count is high, the degree of imprecision increases, $\underline{\partial}$ although not to a degree that is important in practice.

The results provided by the model $S$ areo linear within the ranges met within clinicalo practice for the $\mathrm{Hb}$ concentration, haematocrit, $\frac{\bar{\omega}}{\not{\rho}}$ red call count, and white cell count (see Table IX ${ }_{\odot}^{\mathbb{D}}$ and Figs. 2 and 3). There is a tendency for very low white counts in the 'observed' group to be higher than expected. This may in part be due to. a relative increase in the background count $\overrightarrow{\vec{\omega}}$ compared with the white cell count. In general the background count in the white cell channelso has been in the range $0-300 / \mathrm{cmm}$, which isi clearly insufficient to be of significance in practice. $\omega$ We have been able to detect total white cello counts of less than $500 / \mathrm{c} \mathrm{mm}$ on several occasions, confirmed by manual counting. The effects of $a^{3}$ high white cell count on other parameters have $\vec{\neg}$ not been studied (see Barnard, Carter, Crosland- $\mathbb{D}$ Taylor, and Stewart, 1969). The amount of carryover from one specimen to the next is about $2 \%$, an amount negligible for practical purposes. This is similar to the carryover found for the Coulter model S by Barnard et al and for the Technicon SMA-4 (Lappin et al, 1969), but greater than the carryover reported by Nelson (1969a) for the SMA-7A.

The rate of operation of the model $\mathbf{S}$ is about

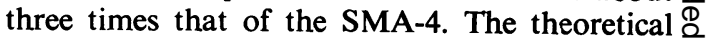
maximum rate is 180 samples per hour, but the $\overrightarrow{\vec{B}}$ usual maximum working rate in practice is about $\cong$ 150 samples per hour. One technician working alone can comfortably achieve 120 samples pero hour.

The Coulter model $\mathbf{S}$ is stable for considerable periods (days or weeks) in the absence of an instrument failure (see below). Recalibration is seldom required more than once weekly. In view of the expense of the standard calibrating reagent, ' $4 \mathrm{C}$ ', we use samples with high and low haemoglobin concentrations and high and low $\frac{D}{2}$ white cell counts each morning, taken from the previous day's work, to check that the instrument $\tilde{\sigma}$ does not require recalibration. In addition a large sample of blood (about $30 \mathrm{ml}$ ) is taken daily and counted at arbitrary intervals during the day to check the stability of the calibration and for the absence of drift. Very high and very low (but feasible) values on any parameter are confirmed by recounting. Discrepancies have seldom been encountered and were probably a consequence of inadequate mixing, and an automatic rocking mixer is now used. Routine inspection of blood smears helps to prevent the reporting of inaccurate white cell counts and red cell indices. Only one gross error was detected in this study (see sample 4, Tables I-IV). The commonest cause of detectable error is now misidentification of a sample at the time of withdrawal. Obviously 
incorrect results (resulting perhaps from electronic or printer failure) are occasionally observed.

The Coulter model S, as presently marketed, requires to be operated manually. While this has the disadvantage of using staff, there are advantages in that a batch of non-urgent blood counts can immediately be set aside to perform emergency work on a 'while-you-wait' basis. Furthermore, the oscilloscope screens, counting chambers, diluting chambers, exhaust chambers, and other working parts are under constant skilled surveillance, allowing prompt detection of defects.

Instrument failures are essentially of two types: minor and readily remediable by trained laboratory staff, and major, requiring highly skilled assistance or spare parts. In general, repairs have been carried out within two or three hours of discovery of a major fault and within minutes for most minor faults; the model $\mathrm{S}$ has not been out of use for more than $\mathbf{2 4}$ hours on any occasion. As a precaution, the equipment required to perform an entire day's work by hand is kept in readiness in case of a major failure. Proximity to a Coulter service facility is obviously an advantage. The importance of careful attention to cleaning and maintenance of the machine is stressed.

It is clear that the Coulter model $\mathbf{S}$ is at least comparable with other automated methods in respect of accuracy and reproducibility and very much more accurate and reproducible than manual methods (see Table VI). It is faster than any other instrument so far developed and offers the opportunity for already overworked laboratories to handle quickly and accurately their increasing workload and, at the same time, permit redeployment of skilled staff to perform other, less easily automated, tasks. The broader implications of automation in the clinical pathology laboratory have been discussed more fully elsewhere (Nelson, 1969b).

References

Barnard, D. F., Carter, A. B., Crosland-Taylor, P. J., and Stewart, J. W. (1969). An evaluation of the Coulter modt S. J. clin. Path., 22, suppl. (Coll. Path.), 3, 26-33.

Bradley, J. V. (1968). Distribution-Free Statistical Tests. Prentịe Hall, Englewood Cliffs, New Jersey.

Brecher, G., Schneiderman, M., and Williams, G. Z. (195) Evaluation of electronic red blood cell counter. Amer.J. clin. Path., 26, 1439-1449.

Dacie, J. V., and Lewis, S. M. (1963). Practical Haematolo 3rd ed. Churchill, London.

Hart, B. I. (1942). Ann. math. Statist., 13, 445.

Lappin, T. R. J., Lamont, A., and Nelson, M. G. (1969). evaluation of the AutoAnalyzer SMA-4. J. clin. Path, 22, 11-18.

Mood, A. M., and Graybill, F. A. (1963). Introduction to the Theory of Statistics. 2nd ed. McGraw-Hill, New York.

Nelson, M. G. (1969a). Multichannel continuous flow analysis on the SMA-4/-7A. J. clin. Path., 22, suppl. (Coll. Path.), 20-25.

Nelson, M. G. (1969b). Automation in the laboratory. $J$. chtst Path., 22, 1-10.

Scheffé, H. (1959). The Analysis of Variance. Wiley, New Yopito 